\title{
Ornamental Variety of Garuda and Wilmana on Padmasana Architecture at Kahyangan Jagat Temple in Bali, Indonesia
}

\author{
Ida Bagus Idedhyana ${ }^{1}$, Ngakan Putu Sueca ${ }^{2}$, Ngakan Ketut Acwin Dwijendra ${ }^{3}$ and Ida Bagus \\ Wirawibawa $^{4}$ \\ ${ }^{1}$ Student of Doctoral Program Engineering Science, Faculty of Engineering, Udayana University and \\ Lecture of Architecture Department, Ngurah Rai University, Denpasar, Bali, Indonesia \\ Email:ib.idedhyana@unr.ac.id \\ ${ }^{2}$ Department of Architecture, Faculty of Engineering, Udayana University, Bali, Indonesia \\ Email:ngakansueca@unud.ac.id \\ ${ }^{3}$ Department of Doctoral Program Engineering Science, Faculty of Engineering, Udayana University, Bali, Indonesia \\ Email: acwin@unud.ac.id \\ ${ }^{4}$ Department of Architecture, Faculty of Engineering, Udayana University, Bali, Indonesia \\ Email: ib_wirawibawa@unud.ac.id
}

\begin{abstract}
Garuda was known in prehistoric India, where his paintings were found in the Harappa (Sindhu River valley), then spread to all corners of the world affected by Indian civilization. Its head, beak and claws are eagles, the light of the gods shining from its body. While Wilmana as a picture of a space vehicle that moves beyond the speed of thought. Wilmana is also a worldwide character, presented in the world of the internet, film and games. Padmasana architecture is a sacred building as a place/position of God, on the back is often carved by the two kinds of decoration. This research about ornamental variety is research in the context of traditional architecture, as an exploration of building concepts that have been developed in the past and are useful to apply to contemporary architecture. This study aims to re-express the meaning of Garuda and Wilmana and how they are placed on Padmasana architecture. The steps taken are to record the Padmasana in the Kahyangan Jagat Temple in Bali, followed by comparing the use of these two types of decoration on each Padmasana. The next step is to interpret the meaning by connecting the object with its past (expanding the horizon of the researcher). The results of the study show that the use of Garuda and Wilmana decoration in the Padmasana architecture is not a necessity. The use of Garuda points to the message that humans must try to free themselves from the bondage of worldly passions. While the use of Wilmana refers to the sky vehicle that carries passengers, both Giant and Dewata to the place they want. Both are symbolic decoration types, have the same position, placed on the body behind the padmasana. The position of the two becomes different if applied together, Garuda is placed in a position above Wilmana, because only a soul that has been freed from worldly slavery can ride Garuda.

Keywords: Ornamental Variety, Garuda, Wilmana, Padmasana Architecture.
\end{abstract}

\section{INTRODUCTION}

The myth of Garuda has been recognized by the people of Bali, but the story of Wilmana still seems unclear. In the world of puppet art both are vehicles of the gods, differing in appearance, one with a bird face and the other with a giant face. Indian Wilmana is very well-known, brought up in cyberspace, films and games. Garuda and Wilmana decoration is used in padmasana, bale gede (traditional house), and in bade (architecture of the dead) [10][11][12]. Both of these decorative styles are also widely applied to contemporary architecture in Bali, such as offices, tourist attractions, hotels and restaurants.

Padmasana architecture is the stana (place/position) of God, a depiction of the entire universe [5]. Padmasana is equipped with pure decoration, constructive decoration, and symbolic decoration. The Padmasana in the Jagyangan Jagat
Temple in Bali places different decoration on the back. Some put Garuda, some used Wilmana, others without Garuda and Wilmana. Such modeling may not be understood by many Balinese Hindu communities. Therefore, re-introduction of the myths, forms, functions, and meanings of these two legendary Hindu icons is needed, so that they are more recognizable, understood and can be applied and developed and adapted to today's architecture.

\section{A. Definition of Ornamental Variety}

Ornamental variety is a decorative incense, generally through the transformation of a plastered form (stylized form) and ornamental value. Decorative type is a variety of ornaments, which is the application of decoration to a product object. Ornament comes from the Latin "ornare" which means adorn. The addition of ornamentation on a 
product object is expected to look more attractive, in aesthetic sense, therefore it can become more valuable or add symbolic value (containing certain purposes). According to [17] ornament is a component of art that is added or deliberately made with the purpose of decoration. [25] describes the various archipelago ornaments can be divided into 2 based on their decorative motifs, namely: 1) geometric ornaments; and 2) organic ornaments. Geometric ornaments are composed of lines and geometric fields, while organic ornaments are representations of objects found in nature. Motives, themes or basic ideas are compositions of forms in nature or invisible natural representations. There are also those that are mere imaginary imaginative and even no longer recognized, called abstract motifs. The presence of ornamental or ornamental arrangements does not only fill in the empty and meaningless parts. Various forms of ornaments have several functions, namely (1) purely aesthetic functions; (2) symbolic functions; (3) technical and constructive functions. The purely aesthetic function is to beautify product objects, the symbolic function is to describe certain meanings, and the technical and structural functions are to support, support, connect, or strengthen construction.

\section{B. Garuda Mythology}

Garuda or Garutman known in the Vedas, in worship myths, are mantras to reach the deepest level of consciousness of all reality. Then Garuda really literally embodied in the Puranas (post-Weda), as a vehicle (vehicle) of Vishnu, as rhythm, sound (saman), and sacrifice (yajnya) [27]. In post-Vedic literature, Garuda is the vehicle of Vishnu, a bird-headed, sparkling brilliant like Agni, and also called Garutmat and Suparna, two terms that have been applied to sun birds in Rigveda [20].

The bird is referred to as 'He who kills dragons or snakes', 'He who eats snakes'. He is the one who has mystical power to the effects of poison. Garuda is a magical sky bird, generally depicted with wings, human arms, legs are vultures, and curved noses form beaks. Garuda is a vehicle, or vahana Vishnu, he bears the deity on his shoulders, raises his sharp hand, a thousand fingers like fiery claws of the sun [28].

\section{Wilmana Mythology}

Wilmana/Walimana is the name of a type of vehicle that can fly in space. The existence of the flying vehicle is mentioned in the Ramayana and Mahabharata books; besides it is also mentioned in the Jaina literature. In the Hindu Puranas it is stated that the Gods have their own vehicles, usually animals or chariots pulled by animals. Kuwera the god of wealth, has a Wilmana, which is a different flying vehicle from the vehicle of the gods in general, and the object was obtained from Brahma. The Wilmana was given the name Puspaka. [21] defines Puspaka as the vehicle of Lord Kuwera. Rawana seized Wilmana from Lord Kuwera, making Wilmana his personal vehicle.

In the story of Bomantaka, when Boma invaded the Daneswara state, burning and destroying its castle, it left behind in the form of Puspaka Manik. Wilmana is taken by Boma, then Boma is the one who drives Wilmana [4]. Wilmana is a vehicle that can bring the rider anywhere, depending on the rider, if the rider is giant Wilmana turns into a demon vehicle (stealth), if the rider Rama, Wilmana becomes a Garuda that rises to the higher layers of sky.

\section{RESEARCH METHOD}

The study was conducted on the Kahyangan Jagat Temple based on the concept of Padma Bhuana (representing nine directions of the wind) in Bali. Observation was carried out by direct observation on the object of research, starting with observing the location, followed by data collection on temple structures, and looking for the existence of Padmasana architecture. Not all temples have Padmasana holy buildings. If it is found, careful observation of its physical form, measurements, sketches and recording images with a digital camera. Data is copied into digital imaging, done carefully to match the original. Then a comparative study is carried out, comparing the decoration used for each padmasana, especially the use of Garuda and Wilmana. To find the meaning interpreted by working with data, organizing data, sorting data into parts and looking for relationships between parts and integration between parts.

To find a deeper meaning, the parts of the horizon expanded by bridging the distance of time, by tracing its past, from the beginning until now, thus the data can begin to be captured meaning. Literature study is the main foundation that continues to be developed in expanding the meaning horizon. Structured interviews were conducted with temple stakeholders, the surrounding community, and with scientists and priests who understood the Padmasana, to support results that were closer to the truth.

\section{A. Research Setting}

Kahyangan Temple in Bali consists of: 1) Besakih Temple; 2) Ulun Danu Batur Temple; 3) Lempuyang Luhur Temple; 4) Andakasa Luhur Temple; 5) Goa Lawah Temple; 6) Luhur Uluwatu Temple; 7) Luhur Batu Karu Temple; 8) Pucak Mangu Temple; 9) and Pusering Jagat Temple. In Batukaru Temple, Luhur Uluwatu Temple, Goa Lawah Temple, and Pucak Mangu Temple no sacred buildings were found in Padmasana (Fig. 1). Thus the study was conducted on Besakih Temple in Karang Asem Regency, Ulun Danu Batur Temple in Bangli Regency, Lempuyang Luhur Temple in Karang Asem Regency, Luhur Andakasa Temple in Karang Asem Regency, and Pusering Jagat Temple in Gianyar Regency.

\section{B. Garuda and Wilmana Ornamental Variety on Padmasana Architecture in the Kahyangan Jagat Temple in Bali}

Besakih Temple and Ulun Danu Batur Temple are Purusha Prakriti, or Rwabhineda Temple. According to [7] purusha contains the highest meaning, which is absolute in one non-dual (single) principle. These are mind, soul-atman, consciousness, Brahman, and absolute. Prakriti is also known as nature, matter, body, maya, and others. Prakriti is the universe worshiped as a mother, is an eco-philosophy perspective very rich and noble. Nature has been described as a mother's status, respect for nature which supports life and feeds all living things. 


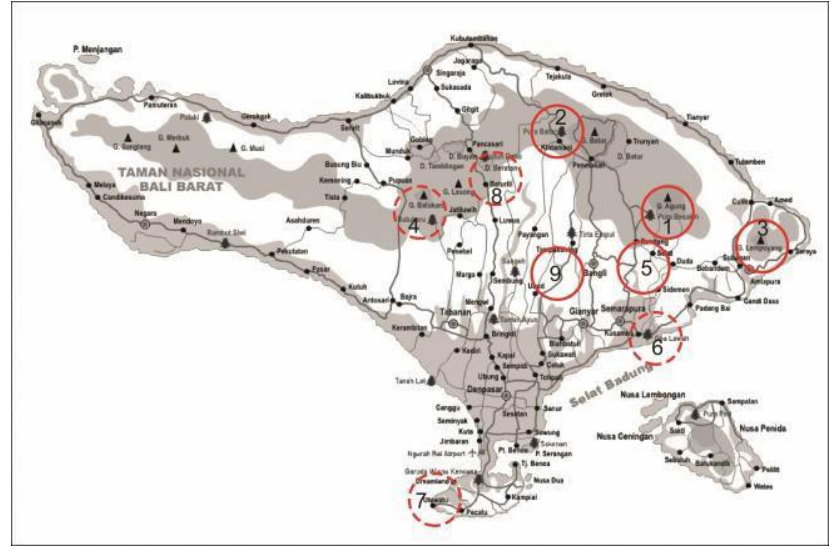

Figure 1. Research Setting

Purusha and prakriti are also termed as purusha and predana, positive-negative, rwabhineda, ardhanareswari. Besakih Temple as purusha, there is a main temple, Penataran Agung Besakih Temple. There is padmasana tiga here, but there are no Garuda or Wilmana decorative types on the back. Ulun Danu Batur Temple as prakriti, using Garuda's decorative ornaments carved on the back of padmasana (Table. 1).

Table. 1. Padmasana in Penataran Agung Besakih Temple and Ulun Danu Batur Temple

\begin{tabular}{|c|c|c|c|}
\hline \multirow{2}{*}{ TEMPLE } & \multicolumn{2}{|c|}{ PADMASANA } & \multirow{2}{*}{ ORNAMENT } \\
\hline & FRONT & BACK & \\
\hline 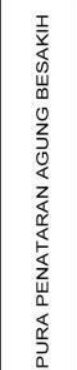 & 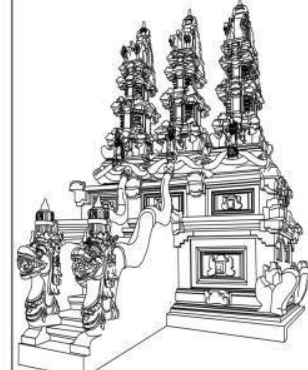 & 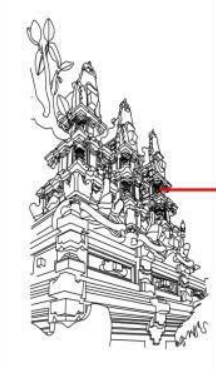 & $\rightarrow \underset{\text { WNTHOUT GARUDA }}{\text { WNIMANA }}$ \\
\hline 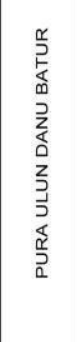 & (1) & 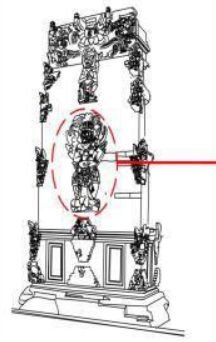 & 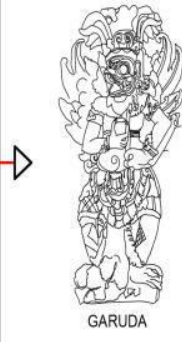 \\
\hline
\end{tabular}

At Luhur Lempuyang and Pusering Jagat Temple, there are padmasana with Garuda decoration as a complement to the back. Luhur Andakasa Templeis different from other temples, Wilmana was chosen as an ornamental variety carved on the back of the padmasana (Table 2).
Table 2. Padmasana in Luhur Lempuyang Temple, Pusering Jagat, Temple and Luhur Andakasa Temple

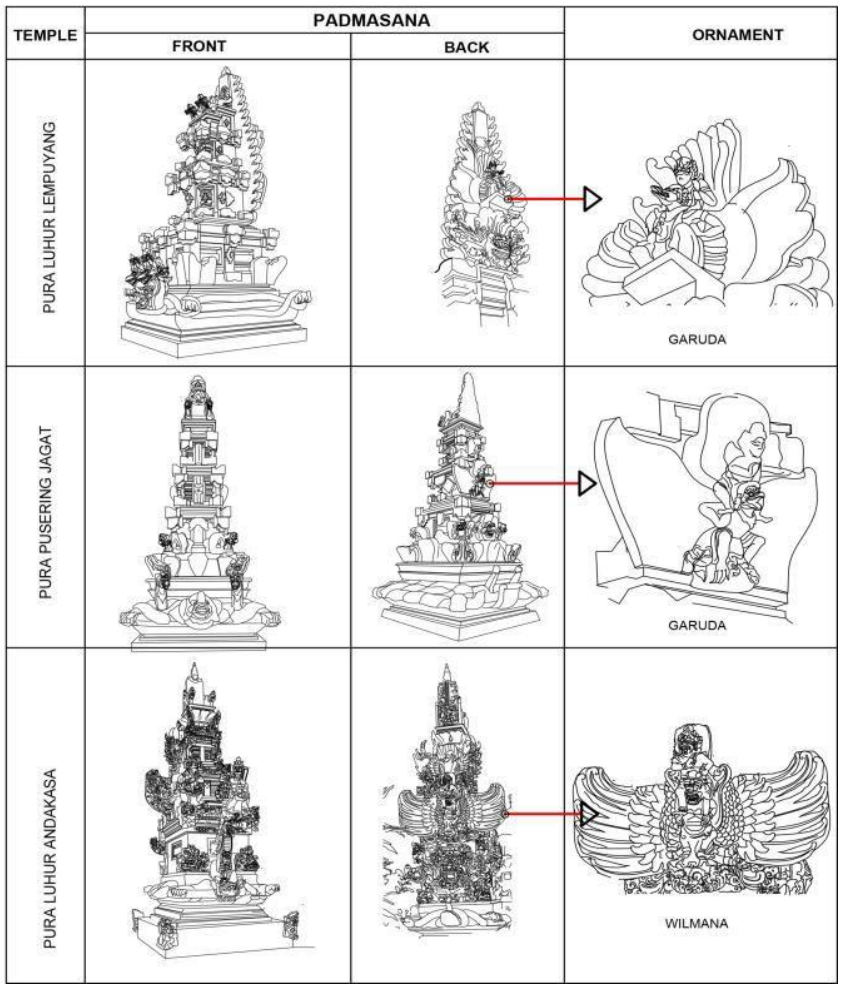

\section{Garuda}

In Java, there are many depictions of the figure of Garuda found in temples, as can be seen in the relief of the Kidal Temple and the statue of the embodiment of Airlangga from Belahan Temple (now in the Trowulan Museum). Garuda was also found in a number of places that were influenced by Hindu-Buddhist culture, such as in Thailand, Tibet and Japan (Fig. 2).

(1)


Figure. 2 Garuda Forms in Several Countries

This figure in Tibet is called Khyung (Kading), is a mystical bird whose shape resembles an eagle but is larger so that it is able to obstruct the sun due to its giant size. In Japan this eagle-human creature called Karura, is imagined to have a breath of fire, golden wings, and wear a jeweled crown that has magical powers on its head.

In Rigveda [3] it is explained: they called him Indra, Mitra, Varuna, Agni, and he was a heavenly winged Garutman. Wise men gave many titles, they called them Agni, Yama, Matarisvan. Descendants of golden-colored birds, in the waters fly to heaven. When it came down to earth, the whole earth was wet with fertility. With various sources, [22] explains that Garuda is also called Tārksya, a mythical human figure who has a bird's beak and claws, as a bird of prey. In the Vedas are described as sun gods. The name Garutman (possibly the prototype Garuda) is associated with the sun, but not as a mount for Viṣnu. Garuda is identified with everything consumed by sunlight, as well as snake predators or destroyers, and hence the nicknames Nāgāntaka and Sarpārāti. Mantram Garuda has the power to heal those who suffer from snakebites and are threatened by illness. The name Garuda was nicknamed Vināyaka, the nickname that he shared with Ganeśa, both of which became the remover or destroyer of obstacles. Rudra is also said to manifest in the form of a mighty heavenly bird. The subsequent development of many of Garuda's stories and tales seems to be taken from ancient stories not from Aryan sources, the original meaning of Garuda has been forgotten. Therefore, they become more than just children's fairy tales like their counterparts in other countries.

In 'Garuda Purana' [8] described Garuda is the king of the bird race, Garuda is described as devotion and sacrifice, blessed to be a Divine vehicle. [19] described Garuda as a mythical creature that might be a prototype of the Phoenix conception. In sculpture it is often seen in a pose with both hands stretched out with palms facing up. This posture signifies support, humility and devotion to Lord Vishnu. The story of the post-Vedic Garuda can be found in the story of 'Adi Parwa' [29], Garuda was born from an egg given by Begawan Kasyapa to his wife Winata, the egg hatched into Garuda. Described as a great bird, when it comes preceded by wind, lightning and light make the eyes go blind, with its wings flapping making lumpy dust, all directions do not seem like covered by clouds. He described the sacrifice and devotion to free his mother from slavery. Garuda is 'ajarascamarasca', 'anadhi', eternal beings do not know aging and death, even without drinking Tirtha Amrta (the holy water of eternity). [26] interpret the birth of Garuda as a liberator of humanity from grave sins.

From the description of the Vedas and post-Vedas, two Garuda images are visible. Initially Garuda was a god associated with the sun, providing prosperity for the world. Garuda is a destroyer of obstacles, he is a holy mantram to destroy disease and poison. Furthermore, the understanding of Garuda developed into a half-divine being but still immortal, a picture of courage, sacrifice, and devotion, in order to free his mother from slavery.
This post-Weda illustration developed in Bali, making Garuda a symbol of human liberation from all attachments and slavery. Humans from birth have been enslaved by their desires/worldly pleasures (like Garuda being enslaved by the dragons), only by virtue, sacrifice, and devotion (Garuda serves Lord Vishnu), all worldly sins and lust can be purified. The Garuda decoration is symbolic, used to decorate the back of the center of the padmasana. Part of the transition between human life to the level of the Gods.

\section{Wilmana}

Wilmana in its Sanskrit language 'Vimana'. Vimana in Sanskrit dictionary means measuring, crossing, chariots of the gods, air cars, resembling ships that can move themselves through the air. Another meaning is a palace, or seven-story tower[23]. The first reference to vehicles capable of traveling in the air with creatures or Gods on board can be found in Rigveda, in hymns addressed to the Twin Gods (Asvin) and other gods. This heavenly vehicle is explained to follow in the footsteps of birds in the sky at speeds exceeding the speed of sound and mind. The word that was originally used to convey the idea of air vehicles was ratha (chariots), soaring toward the sun and moon, usually descending to earth at lightning speed accompanied by a thunderous sound [3].

Literary references in Sanskrit are abundant to support ancient Indian knowledge in air flight. Literary evidence from the Vedic age seems to indicate that Hindus were familiar with various types of metals and chemicals, the evidence also points to the existence of a kind of flying machine from the Vedic era [18]. A Vedic sage named Maharshi Bharadwaja appeared in legitimate Hindu texts. One of these texts is "Vymaanika-Shaastra" is a technical guide for the construction and use of 'Vimanas', flying machines from Vedic stories. This manuscript concerns Aeronautics of three types of Vimanas planes namely Rukma, Sundara, and Shakuna Vimanas (Fig. 3) [6].

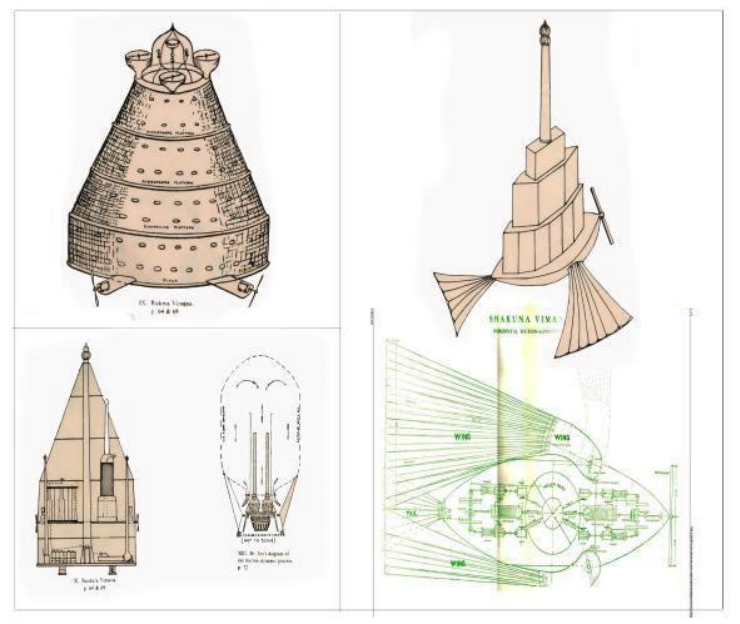

Figure 3. Rukma Vimana, Sundara Vimana and Shakuna Vimana

Source: Bharadwaaja (1973)

The development of Wilmana in areas affected by India is almost the same as the origin of India, in the form of flying 
vehicles or flying terraced houses (Fig. 4). In Indonesia, especially Java and Bali, it is more directed to the Ramayana story, describing Wilmana as a contested great vehicle. [23] [22] describing Wilmana is the vehicle of Lord Kuwera / Kuvera, the mysterious leader of the yakșas, guhyakas and rākșasas. Kubera is one of the eight guards of the world (lokapāla), guardian of the nine divine treasures, guarding minerals and precious stones hidden in the earth. Therefore, he is considered a ruler who dwells in the womb of jewelry. Rawana came to defeat Kuwera, seized his throne, and then kidnapped Sita's wife Rāma during their exile in southern India. Rama came to kill Rawana, captured Wilmana to bring his wife Dewi Sita back to Ayodya. From this story, the shape of Wilmana is depicted as having a giant face, a human body with a crown on its head, having wings like Garuda. On it sits Rawana, Vilmana's next development is as a vehicle for Lord Swayambhu (Fig. 4).

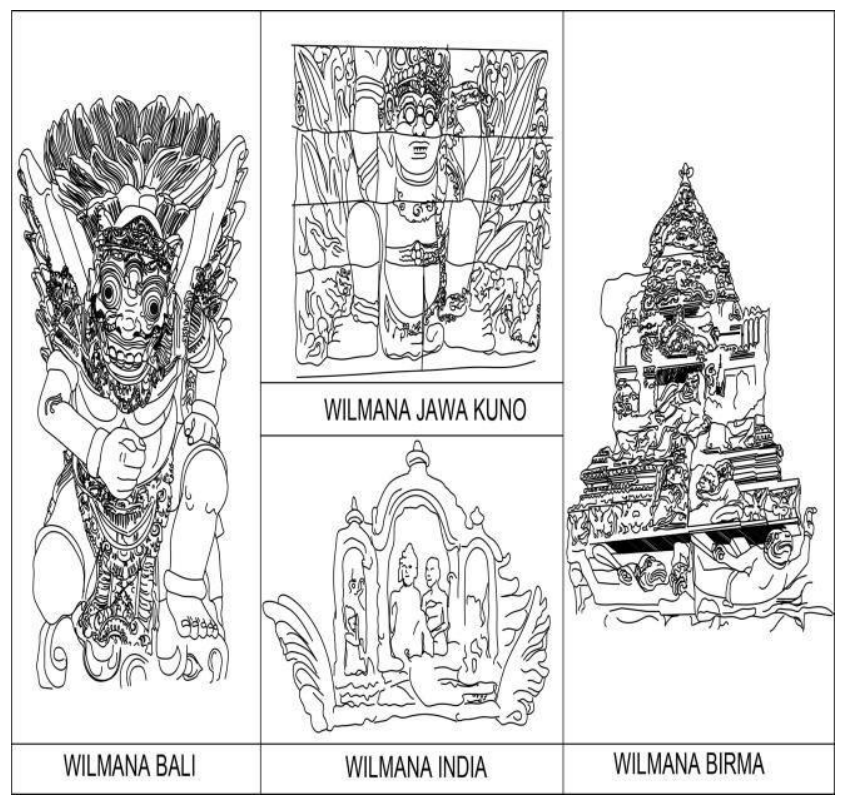

Figure 4. Wilmana in Several Countries

Wilmana is a picture of an aircraft that is able to deliver its passengers, both giants and gods with speeds exceeding the sound and mind, to the desired destination. Wilmana, although the depth of philosophy is not like Garuda, it is still included in the symbolic variety of decoration. Its placement is the same as Garuda's padmasana architecture, which is in the middle, the transition between humans towards the Gods.

\section{CONCLUSION}

Garuda and Wilmana decoration is not a necessity in Padmasana architecture, this decoration is a development of the form of Padmasana in the past. Garuda in Rigveda is the Sun God, everything related to solar energy that provides welfare for the earth. In the era after the Vedas (in the story of Adiparwa, Garuda Purana and other stories) Garuda's status became half divine, but still immortal. The Garuda story is closely related to the efforts of the Gods to obtain Tirtha Amrta in the screenplay of Mandara Giri. Garuda's great journey in freeing his mother from slavery, ended with his humility in serving Lord Vishnu. Garuda became symbolic of the liberation of the spirit from the bondage of worldly passions. Thus Garuda is included in a symbolic variety of decoration, placed in the center of the padmasana, the transition between worldly favors and the release of worldly attachments.

Wilmana in Rigveda is an aerial vehicle, which is able to move beyond the voice and mind, the next description leads to the flight and landing of the Wilmana followed by a booming sound. In the Vedic era there was a manuscript "Vymaanika-Shaastra" about Aircraft made by Maharshi Bharadwaja (presumably living in the Rama dynasty), discovered before World War I by Pandit Subbaraya Sastry. This is where Wilmana began to go global both in the scientific and entertainment world. In Bali, the image of Wilmana is more directed to the vehicle of Rawana and Lord Swayambhu in the northeast direction, depicted with giant faces and human bodies, equipped with wings and crowns. The meaning it contains is still a space vehicle that is able to move beyond the mind, anyone can ride Wilmana as long as it can defeat the previous owner.

Wilmana has the same position as Garuda, equally as a symbolic decoration, placed in the middle at the back of Padmasana architecture. But it will be different if both are applied together, Garuda should be above Wilmana. Garuda still exceeds Wilmana, because no one can drive Garuda except the purified souls, freed from slavery to worldly desires.

\section{REFERENCES}

[1] Acwin Dwijendra, N. K. (2014). Affordable Housing Provision Projects in Bali, Indonesia: Improving Quality and Cultural Acceptability. (Doctoral), Curtin University. Retrieved from http://hdl.handle.net/20.500.11937/2042

[2] Adhika, I Made and Dwijendra, Ngakan Ketut Acwin. (2020). Selfie Photos Area and Its Implication to Water Availability and Social Culture in Wanagiri Village, Bali Indonesia. In: International Journal of Psychosocial Rehabilitation, Vol. 24, No. 4, DOI: 10.37200/IJPR/V24I4/PR201652.

[3] Anonymous. 1896. The Hymns of the Rigveda. Translated by Ralph T. H. Griffith. New Delhi : Munshiram Manoharlal. p. 27, p. 90.

[4] Anonymous. 1990. Bomantaka. Translated by I.W. Warna, Sura. I.G., Sujana, I.N., Japa, I.W., Medera, I.N., dan Alit. I.K. Denpasar: Dinas P\&K Bali. p. 19.

[5] Anonymous. 2000. Himpunan Keputusan Seminar Kesatuan Tafsir Terhadap Aspek-Aspek Agama Hindu I-XV. Denpasar: Pemerintah Propinsi Bali. p. 12, p. 87.

[6] Bharadwaaja, M. 1973. The Vimanika Shastra. Translated by G.R. Josyer. Mysore-4, India: Coronation Press. pp. 1-7.

[7] Choudhury, P. 2005. The Concepts Of Purusa, Prakrti And O La In Sankaradeva's Philosophy. Vol. Doctor, Department of Philosophy. Guwahati: University of Gauhati. p.171, 350-356.

[8] Debroy, B., dan Debroy, D. 2001. Garuda Purana. Surabaya: Paramita. pp. 8-9.

[9] Dharmayanty, Ni Luh Putu Dessy, Paturusi, Syamsul Alam, Dwijendra, Ngakan Ketut Acwin, and Dewi, Ni Ketut Agusinta. (2019), Development and Behaviour Response of the Balinese Inhabitting in Denpasar City and Badung Regency, Bali-Indonesia. In: Journal of Social and Political Sciences, Vol.2, No.2, 455-467.

[10] Dwijendra, NKA (2003). Bali Traditional Housing and Settlements. Journal of Settlement Natah, Vol. 1 No. February 1, 2003: 8 - 24.

[11] Dwijendra, NKA (2008) Arsitektur Rumah Tradisional Bali, Berdasarkan Asta Kosal Kosali, Denpasar: Udayana University Press.

[12] Dwijendra, NKA (2009) Arsitektur Kebudayaan Bali Kuno, Denpasar: Udayana University Press. 
[13] Dwijendra, Ngakan Ketut Acwin (2019) 'Transformation of Traditional Housing in Bungaya Village,Karangasem Bali, Indonesia', International Journal of Current Advanced Research, 08(01),pp.16793-16798. DOI:

http://dx.doi.org/10.24327/ijcar.2019.16798.3118

[14] Dwijendra, Ngakan Ketut Acwin and Sueca, Ngakan Putu. (2019). The Determinant Factor of Home Transformation in Bali, Indonesia, In: The Journal of Social Sciences Research, Vol. 5, No. 12, pp 1855-1860.

[15] Dwijendra, Ngakan Ketut Acwin. (2019), Morphology of House Pattern in Tenganan Dauh Tukad Village, Karangasem Bali, Indonesia. In: Journal of Social and Political Sciences, Vol.2, No.1, 173-181.

[16] Dwijendra, Ngakan Ketut Acwin. (2020). Identity Struggle Perspective in Car-Shaped Shrine in Paluang Temple, Nusa Penida Bali, Indonesia, In: International Journal of Psychosocial Rehabilitation, $\quad$ Vol. $24, \quad$ No. 4 , DOI: 10.37200/IJPR/V24I4/PR201653.

[17] Gustami, S. 2008. Nukilan seni ornamen Indonesia. Yogyakarta: Arindo Nusa Media

[18] Kanjilal, D.K. 1985. Vimana In Ancient India (Aeroplanes Or Flying Machines In Ancient India). Bidhan Sarani, Calcutta: Sanskrit Pustak Bhandar. p. 57.

[19] Liebert, G. 1976. lconographic Dictionary of The Indian Religion: Hinduism-Buddhism-Jainism. Leiden: E.J. Brill.

[20] Macdonell, A.A. 1897. Vedic Mythology. Strassburg: Verlag Von Karl J. Trubner. p. 39, P. 41

[21] Mardiwarsito, L. 1990. Kamus Jawa Kuno Indonesia. IV ed. FloresNTT: Nusa Indah. p. 451.

[22] Margaret, dan Stutley, J. 1977. A Dictionary of Hinduism. London WC1E 7DD and Broadway House: Routledge \& Kegan Paul Ltd. pp. 397-398, pp. 256-258.

[23] Monier-Williams. 1899. Sanskrit-English Dictionary. Amen House, London E.C-4: Oxford University Press. p. 640, p. 980.

[24] Nurjani, Ni Putu Suda, Paturusi, Syamsul Alam, Dwijendra, Ngakan Ketut Acwin, and Putra, I Dewa Gede Agung Diasana. (2019), Morphology of Backpacker Dormitory Inside Traditional Balinese House, Canggu Village, Bali, Indonesia. In: Journal of Social and Political Sciences, Vol.2, No.3, 514-521.

[25] Sunaryo, A. 2009. Ornamen Nusantara. Semarang: Dahara Prize. pp. 3-17.

[26] Wilkins, W.J. 1923. Hindu Mythology, Vedic and Puranic. Calcutta: Thacker, Spink \& Co. pp. 168-169.

[27] Williams, G.M. 2003. Handbook of Hindu Mythology. Santa Barbara, California: ABC-CLIO, Inc. pp. 138-139.

[28] Zimmer, H. 1946. Myths And Symbols In Indian Art And Civilization. Washington, D. C: Bollingen Foundation. p. 76.

[29] Zoetmulder, P.J. 2005. Adiparwa. Surabaya: Paramita. pp.53-76. 